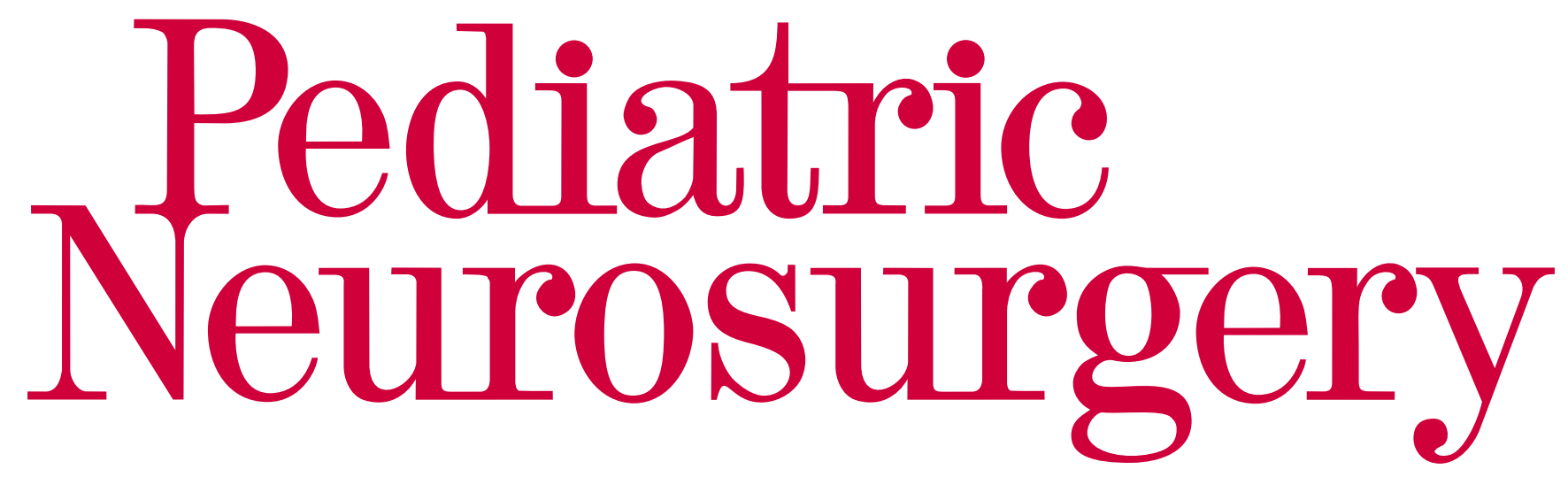

Original Papers

335 Retethering in Children after Sectioning of the Filum Terminale Vassilyadi, M.; Tataryn, Z.; Merziotis, M. (Ottawa, Ont.)

342 Indications for Pediatric External Ventricular Drain Placement and Risk Factors for Conversion to a Ventriculoperitoneal Shunt

Walker, C.T.; Stone, J.J.; Jacobson, M.; Phillips, V.; Silberstein, H.J. (Rochester, N.Y.)

348 Is the Elapsed Time following the Placement of a Ventriculoperitoneal Shunt Catheter an Individual Risk Factor for Shunt Fractures?

Kaplan, M.; Cakin, H.; Ozdemir, N. (Elazig); Gocmez, C. (Diyarbakir); Ozturk, S.; Erol, F.S. (Elazig)

352 The Success of Endoscopic Third Ventriculostomy in Children: Analysis of Prognostic Factors

Furlanetti, L.L. (Ribeirão Preto/Freiburg im Breisgau); Santos, M.V.; de Oliveira, R.S.

(Ribeirão Preto)

360 Spinal Cord Injury without Radiographic Abnormality and the Chiari Malformation: Controlled Observations

Piatt, J.H., Jr.; Campbell, J.W. (Wilmington, Del./Philadelphia, Pa.)

Novel Insights from Clinical Practice

364 Pediatric Cervical Intraosseous Schwannoma

Mohanty, C.B.; Rao, K.V.L.N.; Sampath, S. (Bangalore)

371 A Rare Case of Pediatric Colloid Cysts in Bilateral Ventricles Ma, C.; He, X.; Li, Q.; Jiang, F.; Ma, J. (Shanghai)

374 Inflammatory Pseudotumor of the Lateral Ventricle in a Pediatric Patient

Choi, B.D.; Hodges, T.R.; Grant, G.A.; Fuchs, H.E.; Cummings, T.J.; Muh, C.R. (Durham, N.C.) 


\section{Pediatric Neurosurgery}

(Continued from front cover)

Novel Insights from Clinical Practice

379 Long-Term Survival following Gross Total Resection of Pediatric Supratentorial Ependymomas without Adjuvant Therapy

Tanaka, T.; Kato, N.; Hasegawa, Y.; Nonaka, Y.; Abe, T. (Tokyo)

385 Cauda Equina Syndrome Caused by Spontaneous Bleeding in the Filum Terminale Myxopapillary Ependymoma: A Rare Pediatric Case

Becco de Souza, R.; Brasileiro de Aguiar, G.; Saade, N.; Esteves Veiga, J.C. (São Paulo)

Technical Notes

389 Ascending Transaqueductal Cystoventriculoperitoneal Shunting in Dandy-Walker Malformation: Technical Note

Unal, O.F.; Aras, Y.; Aydoseli, A.; Akcakaya, M.O. (Istanbul)

394 Midline Suboccipital Osteoplastic Craniotomy - ‘Cobra Craniotomy’

Maiti, T.; Bhat, D.I.; Devi, B.I.; Shukla, D. (Bangalore)

Images in Pediatric Neurosurgery

397 Multiple Acquired Encephaloceles: Dramatic End Point of Chronic Untreated Intracranial Hypertension in Multi-Suture Craniosynostosis

Mohseni, M.; Nejat, F.; Chegini, P. (Tehran); El Khashab, M. (Hackensack, N.J.)

after 398 Contents Vol. 48, 2012 


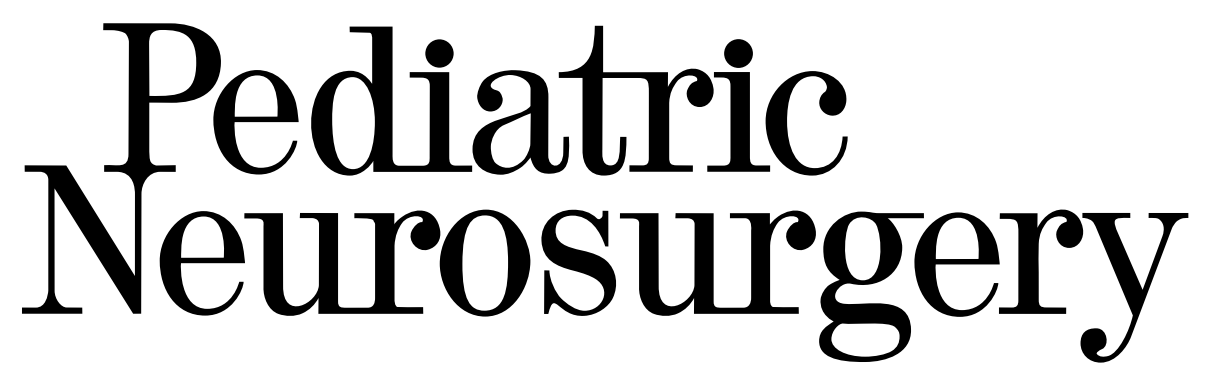

Founded 1985 by E.B. Hendrick and D.H. Reigel

Editor-in-Chief 1985-1991: E.B. Hendrick

Editor-in-Chief 1992-1996: F.J. Epstein

Managing Editor 1985-1998: D.H. Reigel

Editor-in-Chief 1997-2002: D.G. McLone

Managing Editor 1998-2003: M.L. Walker

Editor-in-Chief 2002-2003: W.J. Oakes

Editor-in-Chief 2004-2012: D.M. Frim

\section{Editor-in-Chief}

Timothy M. George, Austin, Tex.

\section{Senior Advisory Board}

D.M. Frim, Chicago, Ill.

J. Gordon McComb,

Los Angeles, Calif.

David G. McLone, Chicago, Ill.

\section{Editorial Board}

H. AbdelAziz, Amman

Y. Aihara, Tokyo

A.M. Avellino, Seattle, Wash.

D.M.E. Bardo, Portland, Oreg.

S. Constantini, Tel Aviv

H.I. El-Shafei, Cairo

T.M. George, Austin, Tex.

J.A. Grant, Kansas City, Kans.

D.K. Gupta, New Delhi

R. Hakim, Beachwood, Ohio

G.I. Jallo, Baltimore, Md.
M. Kohrman, Chicago, Ill.

M.D. Krieger, Los Angeles, Calif.

D.P. Muzumdar, Mumbai

J. Pattisapu, Orlando, Fla.

C. Roberts, Portland, Oreg.

M.U. Schuhmann, Tübingen

N.R. Selden, Portland, Oreg.

S. Sgouros, Athens

M. Stoodley, Sydney, N.S.W.

M. Vassilyadi, Ottawa
Appears bimonthly: 1 volume per year (6 issues) 


\section{Pediatric
Neurosurgery}

\section{Submission}

Only original papers written in English are considered and should be submitted using the online submission website at:

$$
\text { www.karger.com/pne }
$$

or as e-mail attachment (the preferred word-processing package is MS-Word) to the Editorial Office:

\section{pne@karger.com}

S. Karger AG

Editorial Office Pediatric Neurosurgery

$\mathrm{CH}-4009$ Basel (Switzerland)

Tel. +41613061357

\section{Conditions}

All manuscripts are subject to editorial review. Manuscripts are received with the explicit understanding that they are not under simultaneous consideration by any other publication. Submission of an article for publication implies transfer of the copyright from the author to the publisher upon acceptance. Accepted papers become the permanent property of 'Pediatric Neurosurgery' and may not be reproduced by any means, in whole or in part, without the written consent of the publisher. It is the author's responsibility to obtain permission to reproduce illustrations, tables, etc. from other publications.

Sections

The journal consists of the following sections:

- Reviews

- Original Papers

- Novel Insights from Clinical Practice

- Technical Notes

- Images in Pediatric Neurosurgery

- Letters to the Editor

Reviews are either invited by the editor or may be submitted for consideration.

Novel Insights from Clinical Practice (formerly Case Reports): Maximum 7 authors. The publication space available for case reports is very limited. The journal only considers case reports with significant new insights or with an extremely unusual and memorable course. Highlighted boxes containing one or two bullet points on ,Established facts' (what is already known) and ,Novel insights' (what new information has been gained) are required and should be placed on the first page of the report. These should be selected so as to reinforce the novelty of the clinical observation. The text per box should be limited to 1-2 very short sentences. The manuscript should be presented with an abstract (unstructured, max. 200 words), followed by introduction, case report and discussion. Maximum 3 figures.

Technical Note: This section contains articles which describe modern operative techniques in the field of pediatric neurosurgery. Manuscripts should be short and precise and should contain an abstract, 5 key words and 1-4 figures to explain the surgical procedure.

Images in Pediatric Neurosurgery: The section offers the possibility to share an exceptional clinical condition encountered during daily work. Images must be original, unpublished, high-quality black-and-white photographs. The legend/short text should explain the uniqueness of the depicted image and provide relevant clinical information including a short description of the patient's history, relevant physical and laboratory findings, clinical course, response to treatment (if any) and condition, or both. Maximum 8 references, 3 figures; no abstract necessary and no key words.

Letters to the Editor are encouraged if they directly concern articles previously published in this journal and clinical subjects related to the matters discussed. The editor reserves the right to submit copies of such letters to the authors of the articles concerned prior to publication in order to permit them to respond in the same issue of the journal. Letters to the Editor should be no longer than one printed page.

\section{Arrangement}

Title page: The first page of each paper should indicate the title, the authors' names, the institute where the work was conducted, and a short title for use as running head.

Full address: The exact postal address of the corresponding author complete with postal code must be given at the bottom of the title page. Please also supply phone and fax numbers, as well as e-mail address.

Key words: Please supply 3-10 key words in English that reflect the content of the paper.

Abstract: Each paper needs an abstract of up to 10 lines.

Footnotes: Avoid footnotes. When essential, they are numbered consecutively and typed at the foot of the appropriate page.

Tables and illustrations: Tables and illustrations (both numbered in Arabic numerals) should be prepared on separate sheets. Tables require a heading and figures a legend, also prepared on a separate sheet. For the reproduction of illustrations, only good drawings and origina photographs can be accepted; negatives or photocopies cannot be used. Due to technical reasons, figures with a screen background should not be submitted. When possible, group several illustrations on one block for reproduction (max. size $180 \times 223 \mathrm{~mm}$ ) or provide crop marks. Electronically submitted b/w half-tone and color illustrations must have a final resolution of $300 \mathrm{dpi}$ after scaling, line drawings one of 800-1200 dpi.

\section{Color illustrations}

Online edition: Color illustrations are reproduced free of charge. In the print version, the illustrations are reproduced in black and white. Please avoid referring to the colors in the text and figure legends.

Print edition: Up to 6 color illustrations per page can be integrated within the text at CHF 800.- per page.

References: In the text identify references by Arabic numerals [in square brackets]. Material submitted for publication but not yet accepted should be noted as 'unpublished data' and not be included in the reference list. The list of references should include only those publications which are cited in the text. Do not alphabetize; number references in the order in which they are first mentioned in the text. The surnames of the authors followed by initials should be given. There should be no punctuation other than a comma to separate the authors. Preferably, please cite all authors. Abbreviate journal names according to the Index Medicus system. Also see International Committee of Medical Journal Editors: Uniform requirements for manuscripts submitted to biomedical journals (www.icmje.org).

\section{Examples}

(a) Papers published in periodicals: Sun J, Koto H, Chung $\mathrm{KF}$ : Interaction of ozone and allergen challenges on bronchial responsiveness and inflammation in sensitised guinea pigs. Int Arch Allergy Immunol 1997;112:191195.

(b) Papers published only with DOI numbers:

Theoharides TC, Boucher W, Spear K: Serum interleukin-6 reflects disease severity and osteoporosis in mastocytosis patients. Int Arch Allergy Immunol DOI: $10.1159 / 000063858$

(c) Monographs: Matthews DE, Farewell VT: Using and Understanding Medical Statistics, ed 3, revised. Basel, Karger, 1996

(d) Edited books: Parren PWHI, Burton DR: Antibodies against HIV-1 from phage display libraries: Mapping of an immune response and progress towards antiviral im- munotherapy; in Capra JD (ed): Antibody Engineering. Chem Immunol. Basel, Karger, 1997, vol 65, pp 18-56.

Reference Management Software: Use of EndNote is recommended for easy management and formatting of citations and reference lists.

\section{Digital Object Identifier (DOI)}

S. Karger Publishers supports DOIs as unique identifiers for articles. A DOI number will be printed on the title page of each article. DOIs can be useful in the future for identifying and citing articles published online without volume or issue information. More information can be found at www.doi.org.

\section{Supplementary Material}

Supplementary material is restricted to additional data that are not necessary for the scientific integrity and conclusions of the paper. Please note that all supplementary files will undergo editorial review and should be submitted together with the original manuscript. The Editors reserve the right to limit the scope and length of the supplementary material. Supplementary material must meet production quality standards for Web publication without the need for any modification or editing. In general, supplementary files should not exceed $10 \mathrm{MB}$ in size. Al figures and tables should have titles and legends and all files should be supplied separately and named clearly. Acceptable files and formats are: Word or PDF files, Excel spreadsheets (only if the data cannot be converted properly to a PDF file), and video files (.mov, .avi, .mpeg).

\section{Author's Choice ${ }^{\mathrm{TM}}$}

With this option the author can choose to make his article freely available online against a one-time fee of CHF 3000.-. This fee is independent of any standard charges for supplementary pages, color images etc. which may apply. More information can be found at www.karger.com/authors choice.

\section{NIH-Funded Research}

The U.S. National Institutes of Health (NIH) mandates under the NIH Public Access Policy that final, peer-reviewed manuscripts appear in its digital database within 12 months of the official publication date. As a service to authors, Karger submits the final version of your article on your behalf to PubMed Central (PMC) immediately upon publishing. It usually receives a PMCID within approximately a month and will appear in PMC after 12 months. For those selecting our premium Author's Choi$\mathrm{ce}^{\mathrm{TM}}$ service, the usual embargo will be overriden, accelerating the accessibility of your work. More details on NIH's Public Access Policy are available at http://publicaccess.nih.gov/policy.htm

\section{Self-Archiving}

Karger permits authors to archive their pre-prints (i.e. pre-refereeing) or post-prints (i.e. final draft post-refereeing) on their personal or institution's servers, provided the following conditions are met: Articles may not be used for commercial purposes, must be linked to the publisher's version, and must acknowledge the publisher's copyright. Authors selecting Karger's Author's Choice ${ }^{\mathrm{TM}}$ feature, however, are also permitted to archive the final, published version of their article, which includes copyediting and design improvements as well as citation links.

\section{Proofs}

Unless indicated otherwise, proofs are sent to the corresponding author and should be returned with the least possible delay. Alterations made in proofs, other than the correction of printer's errors, are charged to the author.

\section{Reprints}

Order forms and a price list are sent with the proofs. Orders submitted after the issue is printed are subject to considerably higher prices.

\section{KARGER}

E-Mail karger@karger.com www.karger.com
(C) 2012 S. Karger AG, Basel 


\section{Pediatric \\ Neurosurgery}

ISSN Print Edition: 1016-2291

ISSN Online Edition: 1423-0305

Journal Homepage: www.karger.com/pne

Publication Data: 'Pediatric Neurosurgery' is published 6 times a year. Volume 48 with 6 issues appears in 2012 .

Copyright: (c) 2011 S. Karger AG, Basel (Switzerland) All rights reserved. No part of this publication may be translated into other languages, reproduced or utilized in any form or by any means, electronic or mechanical including photocopying, recording, microcopying, or by any information storage and retrieval system, without permission in writing from the publisher or, in the case of photocopying, direct payment of a specified fee to the Copyright Clearance Center.

Disclaimer: The statements, opinions and data contained in this publication are solely those of the individual authors and contributors and not of the publisher and the editor(s). The appearance of advertisements in the journal is not a warranty, endorsement, or approval of the products or services advertised or of their effectiveness, quality or safety. The publisher and the editor(s) disclaim responsibility for any injury to persons or property resulting from any ideas, methods, instructions or products referred to in the content or advertisements.
Subscription Rates: Subscriptions run for a full calendar year. Prices are given per year. Personal subscription

Print or Online

CHF 506.-

EUR 404--

USD 491.00

Print+Online combined

USD 538.00

postage and handling (added to print and print+online)

CHF 40.80 Europe, CHF 60.- Overseas

EUR 31.20

USD 56.40

Institutional subscription

Print or Online

Print+Online combined

CHF 1685.-

EUR 1348.-

CHF 1845.-

postage and handling (added to print and print+online)

CHF 51.00 Europe, CHF 75.00 Overseas

EUR 39.00

USD 70.50

Airmail surcharge: CHF 51.00 / USD 48.00
Back Volumes and Single Issues: Information on availability and prices of single print issues and print or electronic back volumes can be obtained from Customer Service at service@karger.ch.

Bibliographic Indices: This journal is regularly listed in bibliographic services, including Current Contents ${ }^{\circledR}$ and PubMed/MEDLINE.

Photocopying: This journal has been registered with the Copyright Clearance Center (CCC), as indicated by the code appearing on the first page of each article. For readers in the US, this code signals consent for copying of articles for personal or internal use, or for the personal or internal use of specific clients, provided that the stated fee is paid per copy directly to

Copyright Clearance Center Inc.

222 Rosewood Drive

Danvers, MA 01923 (USA)

A copy of the first page of the article must accompany payment. Consent does not extend to copying for general distribution, for promotion, for creating new works, or for resale. In these cases, specific written permission must be obtained from the copyright owner,

S. Karger AG, P.O. Box

CH-4009 Basel (Switzerland).

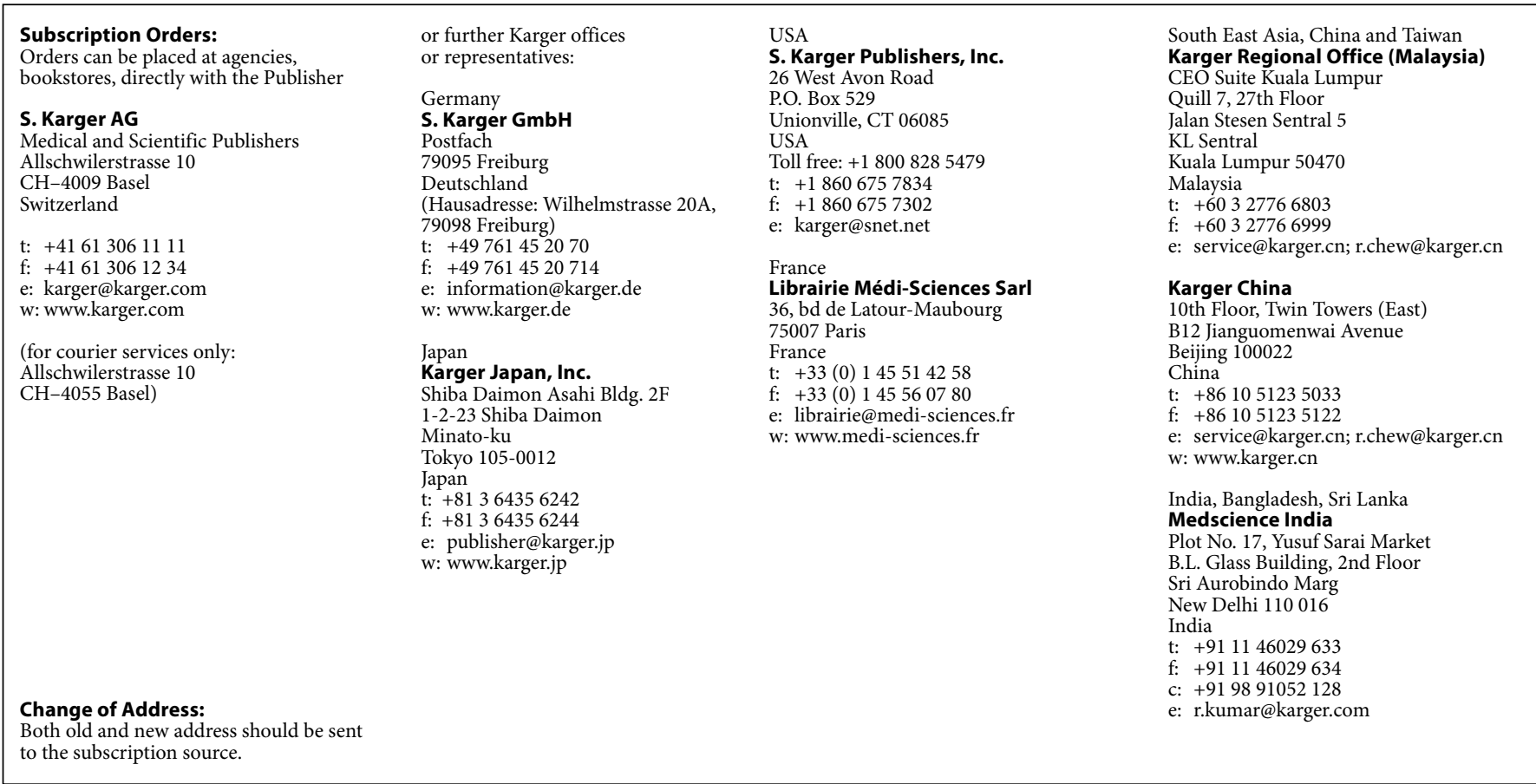

\section{KARGER}

E-Mail karger@karger.com www.karger.com
(C) 2012 S. Karger AG, Basel

The Journal Home Page is available at: www.karger.com/pne 


\section{SUBMIT YOUR ABSTRACT}

a

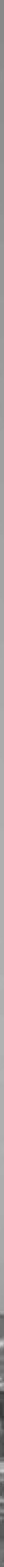

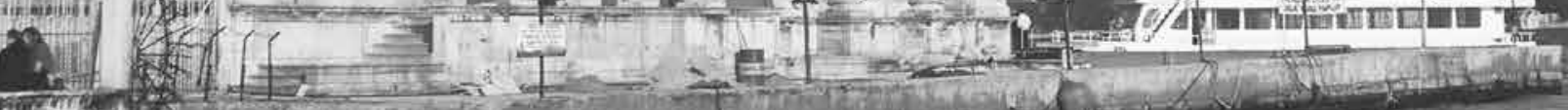

Presented by

Kremesinternational
World Federation of Ped
Critical Care societics

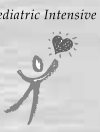

स⿴囗十)
Congress Venue

Istanbul Congress Centre Taskisla Street, Harbiye 34367 Istanbul

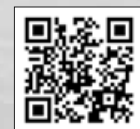




\section{Contents}

See the journal website for contents

KARGER Basel $\bullet$ Freiburg $\cdot$ Paris $\bullet$ London $\bullet$ New York $\cdot$ New Delhi $•$ Bangkok Beijing $\cdot$ Tokyo $\cdot$ Kuala Lumpur $\cdot$ Singapore $\bullet$ Sydney 


\begin{tabular}{|c|c|c|c|c|}
\hline $\begin{array}{l}\text { Series Editor } \\
\text { Schmid, M. (Würzburg) }\end{array}$ & \multicolumn{3}{|c|}{$\begin{array}{l}\text { Results of sophisticated genetic studies } \\
\text { Human genetics represents a highly diversified field covering an ever-increasing number of } \\
\text { topics ranging from basic research to medical practice. The well-established book series } \\
\text { Monographs in Human Genetics focuses on important hereditary diseases, their molecular } \\
\text { basis, clinical impact and eventual treatment. With its concise but highly informative reviews } \\
\text { by experts from different fields, Monographs in Human Genetics provides essential reading } \\
\text { not only for researchers but also for physicians and students interested in specific genetic } \\
\text { diseases. }\end{array}$} & 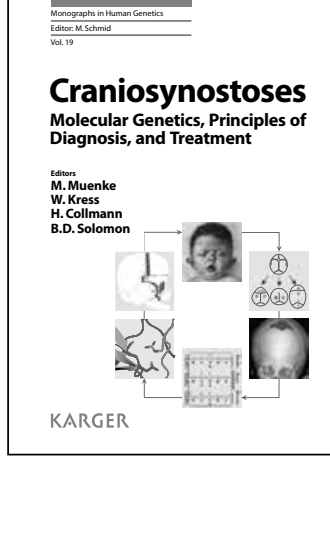 \\
\hline Monographs in Human Genetics & \multirow{5}{*}{$\begin{array}{l}\text { Vol. 19: Craniosynostoses } \\
\text { Molecular Genetics, Principles of Di- } \\
\text { agnosis, and Treatment } \\
\text { Editors: Muenke, M. (Bethesda, Md.); } \\
\text { Kress, W.; Collmann, H. (Würzburg); } \\
\text { Solomon, B.D. (Bethesda, Md.) } \\
\text { X + } 250 \text { p., } 113 \text { fig., } 32 \text { in color, } 17 \text { tab., } \\
\text { hard cover, } 2011 \text {. } \\
\text { CHF 360.- / EUR 300.- / USD } 424.00 \\
\text { ISBN 978-3-8055-9594-0 } \\
\text { e-ISBN 978-3-8055-9595-7 } \\
\text { The definitive volume on } \\
\text { craniosynostosis for many years } \\
\text { to come }\end{array}$} & \multirow{5}{*}{$\begin{array}{l}\text { Vol. 18: Genetics of Mental } \\
\text { Retardation } \\
\text { An Overview Encompassing Learning } \\
\text { Disability and Intellectual Disability } \\
\text { Editor: Knight, S.J.L. (Oxford) } \\
\text { XII + } 166 \text { p., } 31 \text { fig., } 15 \text { in color, } 12 \text { tab., } \\
\text { hard cover, } 2010 \\
\text { CHF 235- - EUR 196.- / USD } 276.00 \\
\text { ISBN 978-3-8055-9280-2 } \\
\text { e-ISBN 978-3-8055-9281-9 } \\
\text { Significant advances in diagnosing } \\
\text { and understanding the genetic causes } \\
\text { of mental retardation }\end{array}$} & \multirow{4}{*}{$\begin{array}{l}\text { Vol. 17: Noonan Syndrome and } \\
\text { Related Disorders - A Matter } \\
\text { of Deregulated Ras Signaling } \\
\text { Editor: Zenker, M. (Erlangen) } \\
\text { X+168 p., } 25 \text { fig., } 17 \text { in color, } 16 \text { tab., } \\
\text { hard cover, } 2009 \\
\text { CHF 198.- / EUR 165.- - USD } 233.00 \\
\text { ISBN } 978-3-8055-8653-5 \\
\text { e-ISBN 978-3-8055-8654-2 } \\
\text { From basic molecular research to } \\
\text { clinical practice }\end{array}$} & \multirow{4}{*}{$\begin{array}{l}\text { Vol. 16: Neurofibromatoses } \\
\text { Editor: Kaufmann, D. (Ulm) } \\
X+192 \text { p., } 28 \text { fig., } 14 \text { in color, } 15 \text { tab., } \\
\text { hard cover, 2008 } \\
\text { CHF 190.- / EUR 158.- / USD } 224.00 \\
\text { ISBN 978-3-8055-8520-0 } \\
\text { e-ISBN 978-3-8055-8521-7 } \\
\text { An overview of recent findings with } \\
\text { a focus on genetics and molecular } \\
\text { biology }\end{array}$} \\
\hline $\begin{array}{l}\text { ISSN 0077-0876 } \\
\text { e-ISSN 1662-3835 } \\
\text { Prices subject to change } \\
\text { EUR price for Germany, } \\
\text { USD price for USA only }\end{array}$ & & & & \\
\hline & & & & \\
\hline 回暷回 & & & & \\
\hline $\begin{array}{l}\text { Read it online: } \\
\text { www.karger.com/mohug }\end{array}$ & & & & \\
\hline
\end{tabular}

\section{'A collection of extraordinary essays'}

\section{GOTTFRIED SCHATZ}

\section{A MATTER OF WONDER}

What Biology Reveals about Us, Our World, and Our Dreams

Where do we come from? Is our destiny determined by the genes we inherit? In this book Gottfried Schatz, the world-renowned biochemist and co-discoverer of mitochondrial DNA, gives lucid - albeit often surprising - answers to universal questions and takes the reader on a fascinating journey of discovery across the boundaries of scientific disciplines. With passion and a keen sense of wonder he draws on philosophy, cultural history and art to formulate his reflections on the mysteries of life. His essays will appeal not only to scientists but to all inquisitive minds, regardless of educational and professional background.

\section{KARGER}

S. Karger AG, P.O. Box $\mathrm{CH}-4009$ Basel (Switzerland)
Fax +41613061234 E-Mail orders@karger.ch www.karger.com

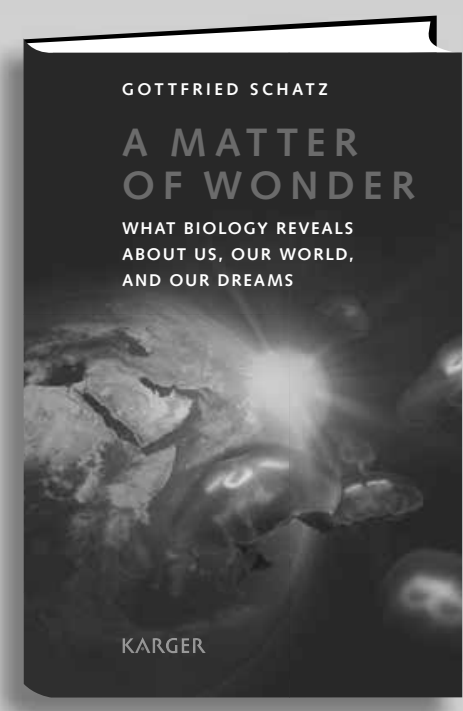

G. Schatz (Basel)

A Matter of Wonder What Biology Reveals about Us, Our World, and Our Dreams Translated by A. Shields XII + 190 p., 2 color fig., hard cover, 2011 CHF 29.-/EUR 21.50/ USD 29.00 ISBN 978-3-8055-9744-9

More information and sample essays at www.karger.com/schatz 


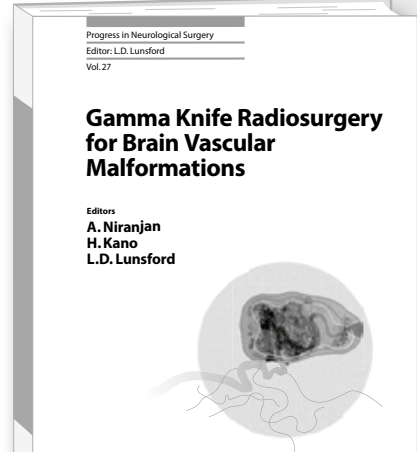

KARGER

\title{
Gamma Knife Radiosurgery for Brain Vascular Malformations
}

\author{
Editors \\ Ajay Niranjan \\ Hideyuki Kano \\ L. Dade Lunsford
}

Gamma Knife Radiosurgery for Brain Vascular Malformations Editors: Niranjan, A.; Kano, H.; Lunsford, L.D. (Pittsburgh, Pa.) VIII + 232 p., 60 fig., 25 in color, 28 tab., 2013 CHF 228.- / EUR 190.- / USD 268.00 (hard cover) CHF 274.- / EUR 228.- / USD 322.00 (online) Online version for institutional purchase Prices subject to change

EUR price for Germany, USD price for USA only ISBN 978-3-8055-9619-0 e-ISBN 978-3-8055-9620-6

Progress in Neurological Surgery, Vol. 27 Series Editor: Lunsford, L.D. (Pittsburgh, Pa)

Dear Librarian

I have reviewed this publication and would like to recommend it for our library. Recommended by:

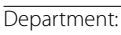

Clinical outcomes of brain vascular malformation have been greatly improved by advances in microsurgery, endovascular techniques and stereotactic radiosurgery. Radiosurgery has proven to be the least invasive technique and is associated with documented long-term success. The papers in this volume present the experience of leading brain vascular malformation specialists who describe the outcome of radiosurgery for arteriovenous malformations, cavernous malformations and dural arteriovenous fistulas. These reviews expand the knowledge of the role of stereotactic radiosurgery alone or in combination with other treatment modalities. Evidence-based guidelines are included in each section to provide a summary of the current management strategies. This unique publication includes additional data that will further define the long-term benefit and risks of radiosurgery for these often complex vascular disorders and makes valuable reading for neurosurgeons, neurologists and endovascular specialists interested in an excellent summary of more than 30 years of accumulated experience in the management of brain vascular malformations.

\section{Contents}

- Series Editor's Note: Lunsford, L.D.

- A Brief History of Arteriovenous Malformation

Radiosurgery: Niranjan, A.; Lunsford, L.D.

- Natural History of Cerebral Arteriovenous Malformations and the Risk of Hemorrhage after Radiosurgery: Yen, C.-P.; Schlesinger, D.; Sheehan, J.P.

- The Technical Evolution of Gamma Knife Radiosurgery for Arteriovenous Malformations: Lunsford, L.D.; Niranjan, A.; Kano, H.; Kondziolka, D.

- Targeting and Conformality in Arteriovenous Malformation Radiosurgery: Paddick, I.; Motti, E.

- Dose Selection in Stereotactic Radiosurgery: Flickinger, J.C.i Kano, H.; Niranjan, A.; Kondziolka, D.; Lunsford, L.D. - Development and Testing of a Radiosurgery-Based Arteriovenous Malformation Grading System: Pollock, B.E.

\section{The easiest way to order: www.karger.com/prnes}

Karger - Medical and Scientific Publishers

$\mathrm{CH}-4009$ Basel, Switzerland

orders@karger.com, f: +4161306 1234

www.karger.com
- Radiosurgery for Brainstem Arteriovenous Malformation: Maruyama, K.; Koga, T.; Niranjan, A.; Kondziolka, D.; Flickinger, J.C.; Lunsford, L.D.

- Multistaged Volumetric Management of Large Arteriovenous Malformations: Kano, H.; Kondziolka, D.; Flickinger, J.C.; Park, K.-J.; Parry, P.V.; Yang, H.; Sirin, S.; Niranjan, A.; Novotny, J., Jr.; Lunsford, L.D.

- Endovascular Embolization in Combination with

Radiosurgery for Treatment of Arteriovenous

Malformations: Miller, R.A.; Jankowitz, B.

- Stereotactic Radiosurgery after Embolization for Arteriovenous Malformations: Kano, H.; Kondziolka, D.; Flickinger, J.C.; Park, K.-J.; lyer, A.; Yang, H.; Liu, X.; Monaco, E.A., III; Niranjan, A.; Lunsford, L.D.

- Long-Term Side Effects of Radiosurgery for Arteriovenous Malformations: Yamamoto, M.; Kawabe, T.; Barfod, B.E.

- Management of Adverse Radiation Effects after Radiosurgery for Arteriovenous Malformations: Monaco, E.A., III; Niranjan, A.; Kano, H.; Flickinger, J.C.; Kondziolka, D.; Lunsford, L.D.

- Morphological Observations in Brain Arteriovenous Malformations after Gamma Knife Radiosurgery: Szeifert, G.T.; Levivier, M.; Lorenzoni, J.; Nyáry, I.; Major, O.; Kemeny, A.A. - Stereotactic Radiosurgery Guideline for the Management of Patients with Intracranial Arteriovenous Malformations: Niranjan, A.; Lunsford, L.D.

- Cavernous Malformations and Hemorrhage Risk: Kondziolka, D.; Monaco, E.A., III; Lunsford, L.D.

- Radiosurgery of Brain Cavernomas - Long-Term Results: Liscak, R.

- Radiosurgical Treatment for Epilepsy Associated with Cavernomas: Lévêque, M.; Carron, R.; Bartolomei, F.; Régis, J. - Stereotactic Radiosurgery Guidelines for the Management of Patients with Intracranial Cavernous Malformations: Niranjan, A.; Lunsford, L.D.

- Intracranial Dural Arteriovenous Fistulas: Natural History and Rationale for Treatment with Stereotactic Radiosurgery: Pan, D.H.-C.; Wu, H.-M.; Kuo, Y.-H.; Chung, W.-Y.; Lee, C.-C.; Guo, W.-Y.

- Stereotactic Radiosurgery with or without Embolization for Intracranial Dural Arteriovenous Fistulas: Yang, H.; Kano, H.; Kondziolka, D.; Niranjan, A.; Flickinger, J.C.; Horowitz, M.B.; Lunsford, L.D.

- Dural Arteriovenous Fistulas and the Role of Gamma Knife Stereotactic Radiosurgery: The Stockholm Experience: Söderman, M.; Dodoo, E.; Karlsson, B.

- Stereotactic Radiosurgery Guidelines for the Management of Patients with Intracranial Dural Arteriovenous Fistulas: Niranjan, A.; Lunsford, L.D. 


\section{Gazètte}

\section{Stimulating reading in and around the world of medicine}

The biomedical themes of the Karger Gazette are topical, urgent, exciting. Its articles, written by experts from all over the world, provide a wide audience with the basic issues, new findings and controversies in a lively and readable style. Alongside invited contributions, each number carries attractively presented support material, such as informative graphics, historical summaries, interviews, or portraits of individuals and institutions. The Karger Gazette is published in newspaper format and appears once a year.

And what's more - it's free!

To see behind the cover, please write or e-mail us, and we'll start your subscription with the latest issue.

www.karger.com/gazette

Current issue:

\section{The Aging Issue}

Read about the causes of the aging process, why aging stops in later adult life, the quiet epidemic of Alzheimer's Disease, internet use by seniors, and more.

\footnotetext{
S. Karger AG

Karger Gazette

Allschwilerstrasse 10

CH-4009 Basel (Switzerland)

E-Mail gazette@karger.com

www.karger.com
}

\section{KARGER}




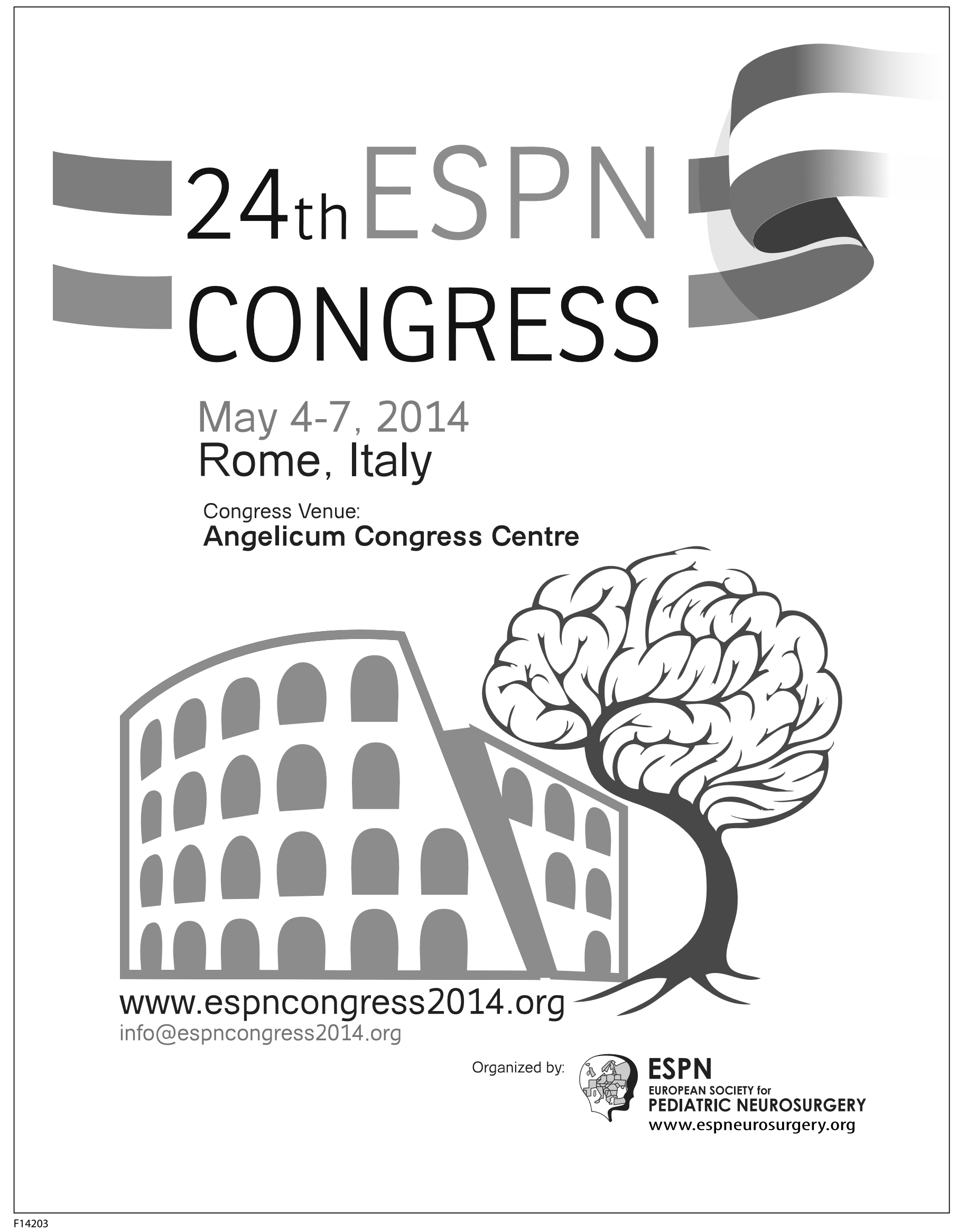

